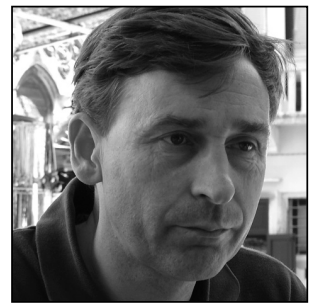

Matthias E. Storme

Professor at the Katholieke Universiteit Leuven and Universiteit Antwerpen

\title{
The Harmonisation
}

\section{of the Law of Personal Security}

In this paper in honour of Prof. Drobnig ${ }^{* 1}$, I would like to deal with the following topics in relation to (the harmonisation of the law of) personal security:

- The level of abstraction fit for a European restatement on this matter (1)

- The structuring of the different institutions in a conceptual and regulatory framework (2)

- The relationship between the specific rules for personal security and general contract law in the proposed Draft Common Frame of Reference ${ }^{* 2}$ (3)

- The rules applicable to provision of proprietary security by a third party (4)

\section{General problems of harmonisation}

The draft common frame of reference tends to formulate rules as much as possible on a general level, and this is clearly also true in the field of personal security. As we will see, many questions are already dealt with in general terms in Book II, on contracts and juridical acts in general, or in Book III, on obligations in general. Further, within the field of personal security, matters are regulated basically for two broad categories of personal security, dependent and independent personal security, with even a substantial general part for both of them.

Is this tendency merely a revival of the Pandectist temptation, as some opponents have cried, reducing the Pandektenschule further unjustly to mere Begriffsjurisprudenz? There are some objective elements explaining and probably also justifying this style. I would like to mention four. All four were to some extent - and mutatis mutandis - also present in the context of $19^{\text {th }}$-century Germany.

1) The lasting importance of freedom of contract, allowing private parties to create new forms or variations of contractual relationships, including personal security. There is no numerus clausus of nominate contracts. This obliges the legislator to use general categories.

2) The growing pressure of the equality principle as a principle of good legislation. Differences in rules have to be justified. Thus, even more than in Germany, private law is weekly under scrutiny by the Belgian Constitutional Court and private law rules are regularly declared unconstitutional because there is not sufficient justification for differences between comparable situations.

\footnotetext{
Presented in German as "Die Harmonisierung der persönlichen Sicherheiten in Europa (Garantien / Bürgschaften), Tagung "Europäisches Kreditsicherungsrecht” zu Ehren von Prof. Dr. Dr. h.c. mult. Ulrich Drobnig aus Anlass seines 80. Geburtstags, Hamburg, 12 December 2008.

2 The complete draft is published as Principles, Definitions and Model Rules of European Private Law - Draft Common Frame of Reference (DCFR), edited by Christian von Bar, Eric Clive and Hans Schulte-Nölke and Hugh Beale, Johnny Herre, Jérôme Huet, Peter Schlechtriem†ं, Matthias Storme, Stephen Swann, Paul Varul, Anna Veneziano and Fryderyk Zoll, in an Outline edition, Sellier 2009 and a full edition later in 2009. Part IV G of the DCFR is in essence the book Personal Security written by Prof. Ulrich Drobnig, published in 2007 in the series Principles of European Law (Study Group on a European Civil Code), with some modifications due to its integration in the whole of the DCFR.
} 
3) The transnational character, which imposes pressure to use categories in which more specific national institutions can be classified.

4) Ockham's razor: where the rule is the same, it is not rational to repeat it many times.

On the other hand, the criticism addressed to such general rules is known also, the well-founded as well as the unfounded criticism. On the one hand, the arguments criticising the intellectual level of abstraction are an expression of laziness. But the arguments criticising the societal level of abstraction, rules abstracted from the concrete societal contexts they regulate, have to be taken seriously. However, this has to be done by providing compensatory mechanisms with an equally general playing field, not pointillist measures.

I have strongly objected to putting 'general principles' in a legal code or DCFR, as these principles are always in competition, contradicting each other, and their balance can only be expressed in rules, not in principles themselves. It is the task of the rules to indicate in which circumstances one or another underlying principle prevails. ${ }^{* 3}$ But this is not an objection against rules of a general character, as long as they are still rules - i.e., containing their conditions of application. It does not make sense to formulate large-scale principles and then add here and there some exceptions without reflection on the principles underlying such exceptions. The balance to be found, e.g., between parties' autonomy and consumer protection is not a balance to be found only for very specific types of cases; it is a more general problem. Many rule-makers tend to formulate consumer protection rules too strictly (as to their field of application), allowing business parties to circumvent them too easily.

Thus any consumer protection legislation that has been drafted in terms of suretyship (Bürgschaft) alone is immediately circumvented by stipulating co-debtorship instead of suretyship in the strict sense, which necessitates 'reparation statutes' to broaden the field of application. We have seen this in Belgium, but it has not prevented the legislator from repeating the same mistake over and over again. The DCFR's Book IV G has rightly chosen to formulate consumer protection for personal security in a general way, in Chapter 4.

By virtue of Article IVG-4:102*4, the rules on dependent personal security will apply to any personal security given by a consumer to a business ${ }^{* 5}$, thus converting independent personal security as well as co-debtorship for security purposes into dependent personal security (Bürgschaft). While co-debtorship for security purposes by a consumer is not explicitly excluded, it follows from Article IVG-4:102 that it too is converted into dependent personal security.

I will illustrate the general tendency in this draft more specifically by analysing two perspectives on the draft rules:

- firstly, the general structure of the different types of personal security and how they fit into the law of obligations in general (2);

- secondly, the relationship between the specific rules and general contract law (3).

\section{Structure of personal security as a type of plurality of debtors}

The basic idea in all cases of personal security is that there are at least three parties involved and that there is some form of plurality of debtors.

\subsection{Dependent and independent security in general}

In most legal traditions, the various forms of plurality of debtors can first of all be classified into the following three general categories:

1) Co-debtors liable for the same obligation, either solidarily or jointly. A performing debtor performs an obligation, which is its 'own' obligation but not merely its own obligation. It is also someone else's obligation, each of them having a 'share' to bear. These situations are in the DCFR governed by Book III, Chapter 4.

\footnotetext{
M. E. Storme "Une question de principe(s)? Réponse à quelques critiques à l'égard du projet provisoire de "Cadre commun de référence", Konferenz "The Draft Common Frame of Reference", European Legal Academy / Europäische Rechtsakademie Trier 6-7 März 2008, 9. ERAForum 2008 Supplement 1, p. S. 65-77. Available at http://webh01.ua.ac.be/storme/ERA-ForumTrier2008.pdf.

4 For the sake of clarity, the conversion of independent security is explicitly provided for in Article IVG-4:105 (c).

With the exception of security providers able to exercise substantial influence upon the debtor where the debtor is not a natural person (Article IV.G-4:101 (2) (b)).
} 
2) A debtor liable for a debt that is the debt of someone else, the main debtor. The first mentioned has no 'share'; internally the debt is apportioned solely to the main debtor. The main figure is the dependent personal security. This category encompasses, in my view, also the cases where a third party grants a proprietary security right to secure someone else's debt (see also 4. below).

3) Two debtors each liable for a different obligation. Their obligations are concurrent, not cumulative, and in the internal relationship the debt is apportioned to one of them while the other has no share to bear. One of the main figures is the independent personal security, in the DCFR governed by Book IV G, Chapter 3.

The 'odd' figure is the co-debtorship for security purposes, where the creditor stipulates that the personal security's guarantor is nevertheless liable as a main debtor. The DCFR has not abolished this figure, except for B-to-C relationships.

The main difference between the second and third category above is evidently expressed by the words 'dependent' and 'independent'. The obligation with the personal security is either dependent on or (wholly or partially) independent from the 'valuta relationship', the relationship between the creditor and the 'main' debtor (whose debt it primarily is). The word 'independent' is to be preferred over 'abstract', because the abstraction of their obligation describes the relationship to the internal relationship between the debtors, the 'provision relationship', and both types of personal security are in principle 'abstract' in that sense.

\section{Figure: Dependent personal security}

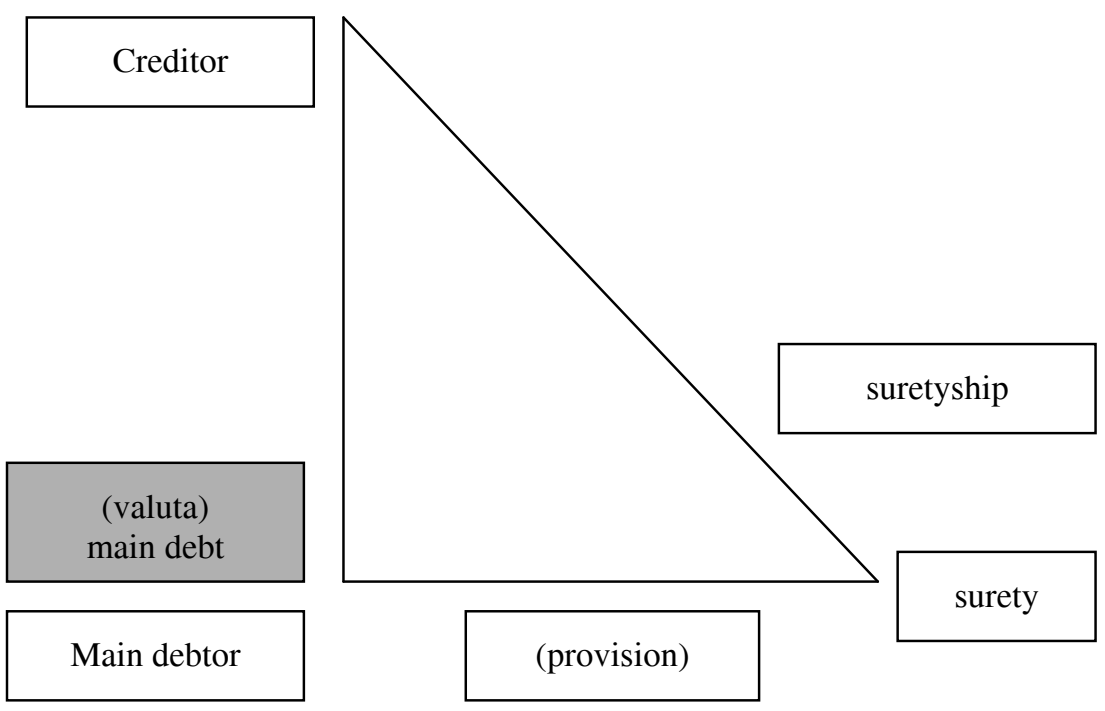

Figure: Independent personal security

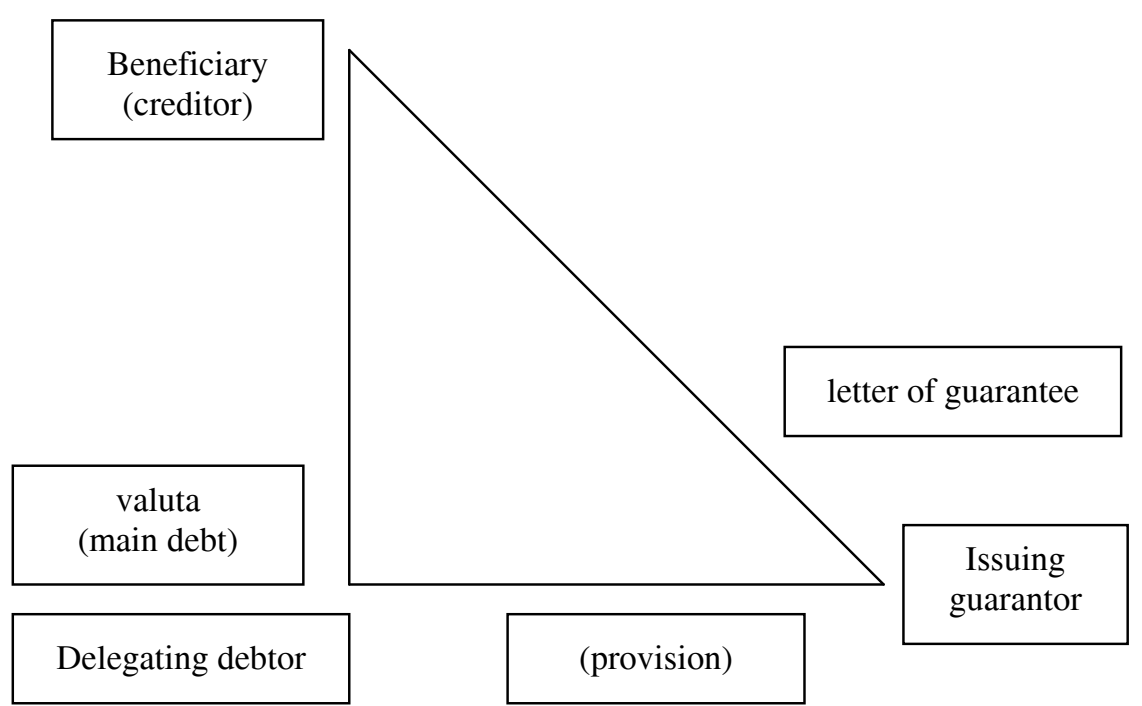




\subsection{Guarantee function and payment function}

The different forms of plurality, or at least the second and third type, can, however, also be classified on the basis of another criterion, according to whether the addition of a debtor has first of all a security (guarantee) function or a payment function. A third possibility is that a new debtor is fully substituting for the old debtor, who is discharged (perfect or complete substitution of a debtor - see Article III-5:203 and 204 of the DCFR).

Leaving aside the last figure, wherein there is no longer a plurality of debtors, this brings us the four following categories of plurality of debtors other than simple co-debtorship.

\begin{tabular}{|l|l|l|}
\hline & $\begin{array}{l}\text { Dependent on valuta relation- } \\
\text { ship }\end{array}$ & Independent from valuta relationship \\
\hline $\begin{array}{l}\text { Guarantee function } \\
\text { shether subsidiary or } \\
\text { solidary) }\end{array}$ & $\begin{array}{l}\text { Dependent personal security } \\
\text { Subsidiary liability, old debtor }\end{array}$ & $\begin{array}{l}\text { Independent personal security } \\
\text { - borderline cases: demand guarantees; } \\
\text { standby letter of credit }\end{array}$ \\
\hline Payment function & $\begin{array}{l}\text { Dependent delegatio solvendi, } \\
\text { such as contract bonds } \\
\text { Compare substitute debtor } \\
\text { when old debtor not discharged }\end{array}$ & $\begin{array}{l}\text { Independent delegatio solvendi, such as: } \\
\text { - credit card } \\
\text { - documentary credit } \\
\text { - money transfer } \\
\text { - bill of exchange }\end{array}$ \\
\hline
\end{tabular}

The distinction between security instruments and payment instruments is not absolute, and intermediate figures are in principle possible. The whole matter is in a certain sense law of obligations in its purest form: the rules express the relation between the different party relationships involved. Nevertheless, it is possible for a legislator to, for reasons of consumer protection or more generally transparency for the market participants, introduce a certain Typenzwang or convert divergent figures into one of the pre-established ones. The latter policy has indeed been followed in the DCFR for personal security provided by a consumer to a business.

\subsection{Classification of the internal relationship}

One can also classify the situations according to the intended effect in the internal relationship between the different debtors: is the performing party engaging itself to pay an existing debt toward the main debtor (solvendi causa), to obtain a claim for reimbursement and perhaps remuneration (credendi causa), or gratuitously (donandi causa)? This distinction does, however, only have an indirect effect on the obligation of the debtors towards the creditor and is therefore not used in the given scheme.

The internal relationship is, on the other hand, interesting from the standpoint of proprietary security, something that may seem curious at first sight. If the delegating debtor requests the delegated debtor to engage itself towards the creditor - especially by drawing a bill of exchange or a cheque - in many national systems and some uniform laws this request amounts to a disposition of the right to performance that the delegating debtor has against the delegated debtor, a disposition in favour of the creditor. Where the delegated debtor is indeed becoming a debtor of the creditor, this does not matter very much, but where it doesn't, the creditor has a proprietary security right in the delegator's right against the delegated party.

\subsection{Four basic types}

Where do we find these four categories in the DCFR?

1. 'Dependent' obligations with a guarantee function: We find them mainly in the form of the dependent personal security in Book IV G, Chapters 2 and 4, discussed in more detail infra. The DCFR has rightly chosen functional and neutral terminology.

We also find them in the case of an incomplete substitution of debtor, where the old debtor has a similar function, in Article III-5:206 and 5:207. The remaining obligation of the old debtor certainly has a guarantee function, although it is not 'dependent' in the strict sense, as it was the original obligation. Article III-5:207 thus provides that

"(1) The effects of an incomplete substitution on defences and set-off are the same as the effects of a complete substitution. 
(2) To the extent that the original debtor is not discharged, any personal or proprietary security provided for the performance of that debtor's obligations is unaffected by the substitution.

(3) So far as not inconsistent with paragraphs (1) and (2) the liability of the original debtor is governed by the rules on the liability of a provider of dependent personal security with subsidiary liability."

2. 'Independent' obligations with a guarantee function. We find them as "independent personal security" in Book IV G, Chapter 3, also discussed infra. Here again, the DCFR has rightly chosen functional and neutral terminology.

3. 'Dependent' obligations with a payment function. The third category is found in the delegatio solvendi where the obligation of the additional debtor is not independent in the sense of not being abstracted from the original or valuta relationship.

Figure: Dependent delegatio solvendi

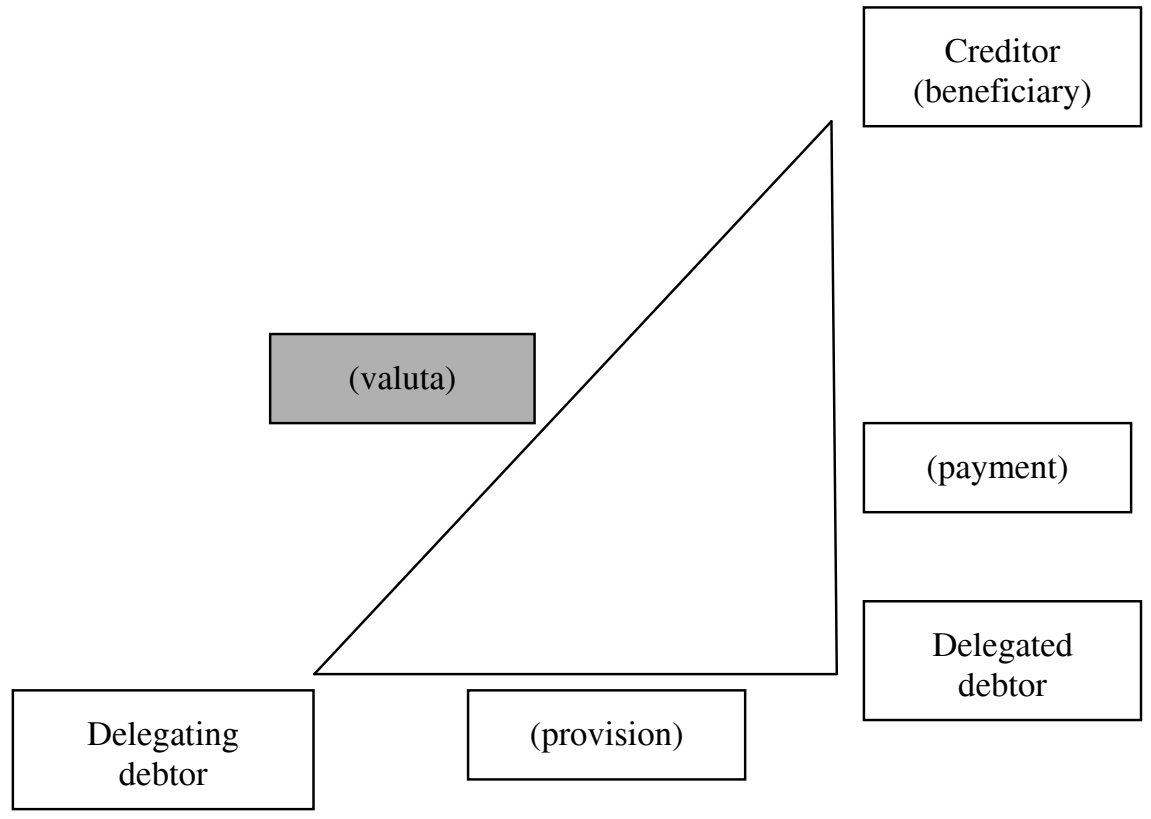

This figure is not regulated by the DCFR but is in a certain sense the mirror image of the incomplete substitution of debtor of Article III-5:206. Where the creditor has accepted the delegation, it has to pursue performance from the delegated debtor in the first place and the original debtor is now merely a subsidiary debtor, although in the internal relationship between both debtors he has to bear the full obligation. The relationship between the creditor and its debtor will determine whether the creditor is obliged to accept a delegation of debt by its debtor to a delegated debtor. As long as the creditor neither accepts the delegation nor is bound to accept, the old debtor remains bound unconditionally and will be discharged only if the third party effectively pays for the account of the old debtor.

4. 'Independent' obligations with a payment function: The final category is, again, a delegatio solvendi, but it is one where the delegated debtor engages in an obligation that is not dependent upon the original obligation. The conditions under which the delegated debtor is bound (i.e., the modalities of his obligation) are a question of interpretation of his promise. This figure too is not regulated by the DCFR, although some aspects can be traced - e.g., in Article III-2:108 (2), which provides that "a creditor who accepts a cheque or other order to pay or a promise to pay is presumed to do so only on condition that it will be honoured. The creditor may not enforce the original obligation to pay unless the order or promise is not honoured". Here, too, the 'main' debtor becomes a subsidiary debtor in the relationship with the creditor. 
Figure: Independent delegatio solvendi

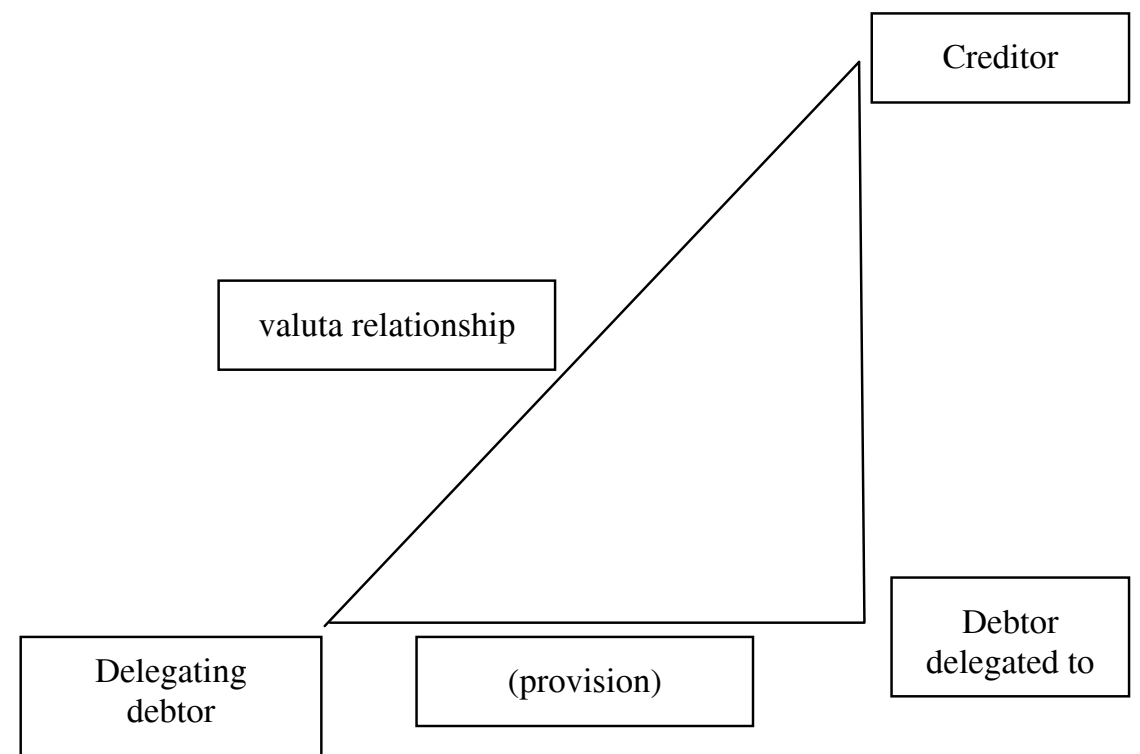

An example mentioned in the Comments to Book IV G is the letter of credit in a documentary credit.

\section{Figure: Documentary credit}

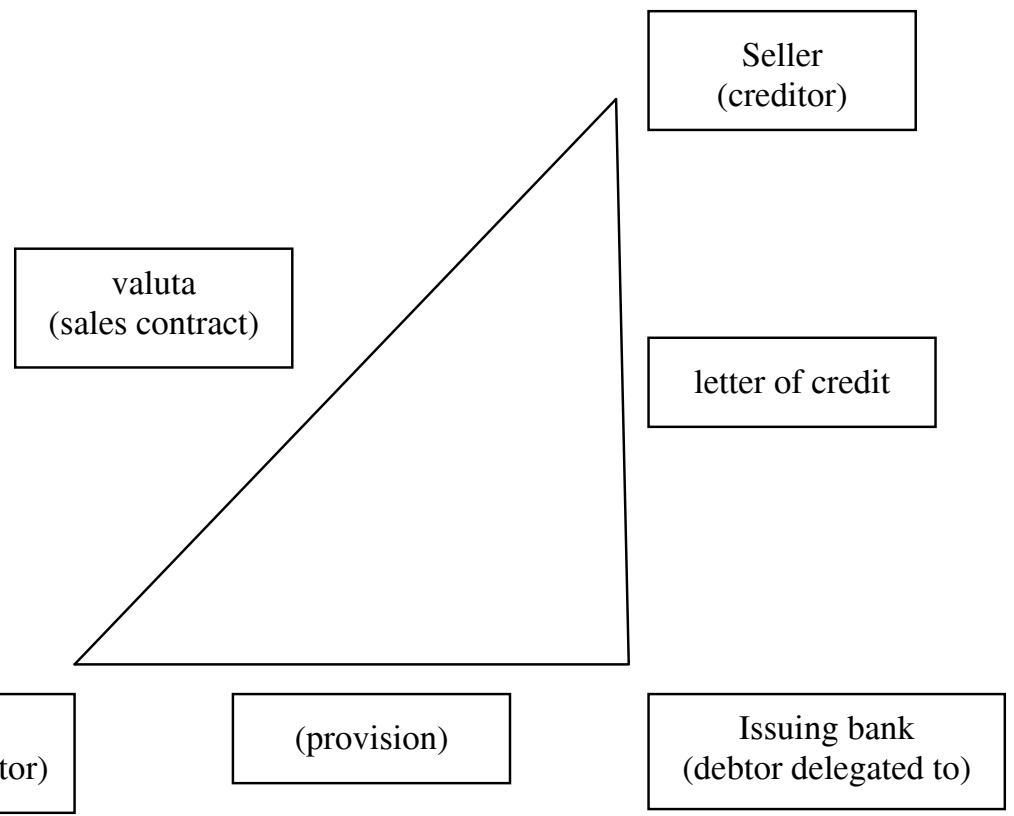

Other examples are the various payment instruments, such as credit cards, bills of exchange, and even simple money transfer. Some elements of these figures are governed by acquis rules, especially in the Payment Services Directive. That directive does not, however, elaborate on the basic infrastructure of payment instruments in the general law of obligations. 


\subsection{The main content of personal security}

Dependent personal security and independent personal security differ from each other in the role the valuta relationship plays. More precisely, this follows from the different modes in which the terms of the obligation are determined:

1) In cases of independent security, the terms of the obligation are determined in principle by the contract with the creditor in itself, without reference to one or more secured obligations.

2) In the case of dependent security, the terms of the obligation are primarily limited in a double way:

- by the extent of the obligations of the main debtor;

- by the extent to which these obligations are 'covered' by the security (an extent that cannot be completely unlimited).

The notion of coverage combines these two cumulative limitations. Fortunately, the DCFR does not follow a certain tendency seen in the French and Belgian doctrine to see two different obligations on the side of the security, a so-called obligation de garantie and obligation de payement; there is only one obligation of the security, but the content of that single obligation is determined by the notion of coverage, which refers to covered obligations of the main debtor.

Apart from the limitation of coverage, the obligation can also be limited by other terms, such as a time for resort to the security (Article IVG-2:108) or other modes of extinction or modalities of the obligation of the security provider (e.g., its possible subsidiary character). As it would go against public policy for the obligation of the security to be able to increase indefinitely because the agreed coverage is 'global', the object of the obligation can by notice be limited to obligations that have arisen before the end of the notice period (see infra).

\section{Relationship with the general law of contracts and obligations}

National systems also differ in the extent to which they rely on general contract law and general law of obligations. In the DCFR, personal security is to a large extent governed by the general law of obligations.

\subsection{Formation}

Apart from slight precision in Article IVG-1:103 on creditor's acceptance, there are no specific rules on formation or personal security in general. This corresponds to the general approach of the DCFR to specific contracts. In B-to-C contracts, however, writing and signature are required by Article IVG-4:104. In all other respects, the rules of Book II's Chapter 4 apply (and some rules relating to formation found elsewhere, such as the rule in II-9:103 on the integration of terms not individually negotiated).

\subsection{Pre-contractual information duties}

The most important rule in this respect is a specific rule applicable when the security giver is a consumer, stated in Article IVG-4:103, paragraph 1:

"the creditor has a duty to explain to the intending security provider:

(a) the general effect of the intended security; and

(b) the special risks to which the security provider may according to the information accessible to the creditor be exposed in view of the financial situation of the debtor."

In the general contract law, there is no corresponding rule. The specific articles on pre-contractual information duties in the DCFR's Book II, Chapter 3, including the general duty set forth in Article II-3:101, only apply to businesses supplying goods and services; thus, they do not apply to creditors stipulating a personal security. They will, on the other hand, apply to professional security givers such as banks, who do provide services when they provide personal security - depending on the circumstances, the service can be a service toward the creditor or toward the main debtor, or toward both. The more specific rules of Article II-3:102 ff. in any case will only apply if the security giver is providing a service to a consumer. A bank securing the right to payment of rent may have an information duty towards the landlord and/or the tenant, depending on their status as consumer. Given the content of these rules, however, they will only play a marginal role and 
probably only in the internal relationship between professional security giver and main debtor (as to their mutual obligations).

Apart from these, information duties can follow indirectly from the general rules on mistake and other defects of consent. Relevant here are only the cases of a defect of consent on the side of the security giver, especially mistake caused by the other party (by giving incorrect information) (II-7:201 (1) (b) (1)), a mistake known by or apparent to the other party and not disclosed (II-7:201 (1) (b) (2)), and consent induced through the fraudulent non-disclosure of information that good faith and fair dealing required the other party to disclose (II-7:205). The latter article in its third paragraph states criteria for information duties, which in my view belong rather more in a general article than in the fraud article alone. The paragraph states that

"regard should be had to all the circumstances, including:

(a) whether the party had special expertise;

(b) the cost to the party of acquiring the relevant information;

(c) whether the other party could reasonably acquire the information by other means; and

(d) the apparent importance of the information to the other party."

These information duties apply to all parties, not merely creditors stipulating an obligation of a consumer. There clearly is a difference in the greater protection of consumers under Article IVG-4:103, paragraph 1:

- In relation to consumers, the creditor who has information regarding the financial situation of the main debtor cannot hide behind the duty of the security giver to inform itself.

- In relation to the content of the obligation, there is basically a duty to explain the effects to a consumer. This is corroborated by more specific duties following from other articles, especially Article IVG-4:105 (a): where no maximum amount is agreed upon with the consumer-security provider, the obligation of the security provider is necessarily limited to the value of the secured rights at the time the security becomes effective.

The absence of a more specific information duty for all contracts for personal security is obviously a compromise between the very different national laws; the complexity of the relationship made it more difficult to go forward in this part of the DCFR than, for example, in the part on services (Book IV C).

\subsection{Validity: Defects of consent}

Recent developments in the law on personal securities have to a large extent been focused on the area of defects of consent. The DCFR does not add many specific rules to the general rules in Book II, Chapter 7.

As to mistake and fraud, apart from the additional content of information duties (already mentioned), there is a slight difference following from Article IVG-4:103, paragraph 4, as the contract can be avoided at any time, whereas in general contract law notice must be given within a reasonable time, according to Article II-7:210. As to the general rules on mistake and fraud, attention must also be given to Article II-7:208:

- Where the main debtor is guilty of fraud in relation to the conclusion of the security contract by the security provider, the security provider can avoid the security contract if the creditor knew or could reasonably be expected to have known of the facts (Article II-7:208 (2)).

- Where the main debtor is, moreover, with the creditor's assent involved in the making of the security contract, the causing of a mistake or fraud is attributed to the creditor itself, irrespective of that knowledge (Article II-7:208 (1)).

Important additions to the general rules are found in relation to abuse of circumstances or 'unfair exploitation'. Article II-7:207 does not deal in itself with cases where the security provider is in a relationship of trust or dependency with the main debtor; it addresses only cases of such relationship with the creditor. Article IVG-4:103 thus gives a more specific rule for a relationship of trust or confidence between the consumer security provider and the main debtor: as soon as the creditor (being a business) knows or has reason to know that there is a significant risk that the security provider is not acting freely or with adequate information, the creditor must ascertain that the security provider has received independent advice and has enjoyed a period for reflection of at least five days. Where the issue is not merely knowledge of a significant risk but knowledge or constructive knowledge of an actual unfair exploitation of the security provider's dependency, trust, or other weaknesses (improvidence, ignorance, or inexperience - see Article II-7:207 (1) (a)) by the main debtor, the general rule of II-7:207 iuncto II-7:208 (2) applies and the security provider can avoid the contract whether or not it is a B-to-C contract. Equally, where the main debtor is with the creditor's assent involved in the making of the security contract, the unfair exploitation by the principal is attributed to the creditor itself, irrespective of such knowledge and irrespective of the business or consumer character ( $c f$. Article II-7:208 (1)). 


\subsection{Withdrawal right in contracts negotiated away from business premises}

The Book on personal security has no specific rules on withdrawal rights, as Article II-5:201 on contracts negotiated away from business premises explicitly also covers personal security granted by a consumer. The withdrawal period of 14 days starts when the contract is concluded and adequate notice of the withdrawal right is given; it ends one year after conclusion, even if such notice has not been given (see Article II-5:103).

\subsection{Interpretation}

As regards interpretation, here, too the general rules apply. Relevant are, i.a., the general rule of II-8:101, the rule of interpretation against the dominant party in II-8:103, and the preference for negotiated terms in II-8:104.

Book IV G adds a "presumption" for dependent personal security (rather than independent security or co-debtorship) in Article IVG-2:101, which can, however, also be understood as a default rule (in exactly the manner in which the non-subsidiary character outside B-to-C contracts, the non-global character, and the limitability of security not limited to specific obligations are default rules — see Articles IVG-2:105, IVG-2:102 (3), and IVG-2:109).

\subsection{Contents and modalities of performance - 'external' relationship}

Evidently, the main topic on which Book IV G takes over from the general law of contracts and obligations in Books II and III is the content of the contract, i.e., the rights and obligations arising out of the contract and their specific modalities.

Thus, Book IV G states as a default rule that personal security is dependent on the debtor's obligation (IVG-2:101) and subject to all defences of the debtor (IVG-2:103), with the exception of some personal defences (Article IVG-2:102 (2) (a) to (c)); where the security is nevertheless an independent security, Chapter 3 contains more specific default rules.

Further, it contains, in essence, the following rules for dependent personal security:

- The default rule that a dependent personal security covers only an existing right of the creditor against the debtor and only up to the value of the secured right at the time the security becomes effective plus the ancillary obligations of the debtor (Articles IVG-2:102 (3) and IVG-2:104 (1 and $2)$ ) and that later agreements between the creditor and the main debtor do not extend that coverage or otherwise adversely affect the obligation of the security provider (see Article IVG-2:102 (4)).

- A notification duty for the creditor in case of events of non-performance by the main debtor (Article IVG-2:107 (1)) and a more general annual notification duty of the creditor in B-to-C contracts (Article IVG-4:106).

- A rule of interpretation when a time limit for resort to a security has been agreed upon (in Article IVG-2:108, a more specific rule when compared to the general rule on time-limited obligations in Article III-1:107).

- Specific rules for the case in which a security is neither limited to cover specific obligations nor limited to cover obligations arising before an agreed time limit — namely, the limitability of the security via notice of (at least) three months (Article IVG-2:109). This rule replaces the general rule of Article III-1:109 (2) on continuous or periodic performances for an unlimited period of time, which requires merely a reasonable period of notice. In B-to-C contracts, any time limit of more than three years can be set by the consumer, given its possibility to limit the coverage to existing obligations by giving notice of at least three months (Article IVG-4:107).

- Specific rules for the case wherein a global security has been agreed on (in derogation from IVG-2:102 (3 and 4)), such as the limitation to rights arising from contracts between the creditor and the main debtor (Article IVG-2:104 (3)), the necessity of a maximum amount in B-to-C contracts (Article IVG-4:105 (a)), and additional notification duties in certain cases of increase (Article IVG-2:107 (2)).

- As a default rule outside B-to-C contracts: the solidarity between the security provider and the main debtor (Article IVG-2:105), but equally a rule in case subsidiary liability has been agreed upon (see Article IVG-2:106); 
- A duty of care of the creditor to maintain the security provider's right to subrogation or recourse/ reimbursement from the debtor (Article IVG-2:110).

In cases of independent personal security:

- The contents of the obligation are determined not by the delimitation of 'coverage' given to obligations of the main debtor but by requirements for a demand for performance. The security provider can only invoke defences out of its own relationship with the creditor, including evidently that the demand does not comply with the terms of the obligation (Article IVG-3:103 (1 and 2)); this rule is restricted in cases of guarantees on first demand (Article IVG-3:104). The security provider cannot invoke defences from the relationship between the main debtor and the creditor, except where the creditor's demand for performance is manifestly abusive or fraudulent (Article IVG-3:105).

- There is also a rule of interpretation in cases where a time limit for resort to a security has been agreed upon (Article IVG-3:107).

- There is a default rule on the time of performance (Article IVG-3:103 (3)).

These rules are not mandatory except in B-to-C contracts (which are always converted into dependent personal security). In other relationships, only the general limitations to freedom of contract apply, such as can be found in the chapter on validity (Book II, Chapter 7) and the rules on the duty of transparency in terms not individually negotiated (Article II-9:402), and on unfair terms (Article II-9:404 for contracts between non-business parties and II-9:405 for contracts between business parties). As Article II-9:406 (2) recalls, for contract terms drafted in plain and intelligible language, the unfairness test extends neither to the definition of the main subject matter of the contract nor to the adequacy of the price to be paid.

Some terms of the relationship arising out of contracts of personal security are determined by general rules of the law of obligations, such as the duty to act in accordance with good faith and fair dealing (Article III-1:103), the duty to co-operate for the performance of the obligations (Article III-1:104), the duty not to discriminate on forbidden grounds in the exercise of a right to performance (Article III-1:105), and the rules on the modalities of performance (Articles III-2:101 to III-2:109 and III-2:111 to III-2:113, except insofar as the more specific rules of IV G deviate from them ${ }^{*}$ ).

\subsection{Non-performance, remedies, and extinction}

The specific part on personal security in Book IV G contains very few rules concerning non-performance of obligations or extinction. ${ }^{* 7}$ Nearly all of the more specific rules on performance and non-performance relate to reduction of rights as a remedy for requirements for the parties, requirements that are, technically speaking, neither duties nor obligations but mere charges or Obliegenheiten. See, e.g., Article IVG-2:107 (4) concerning the remedy in cases of non-notification by the creditor, IVG-2:110 concerning the reduction of creditor's rights for lack of care, and IVG-2:112 c.q. IVG-3:102 on the reduction of the security provider's rights of recourse or subrogation in case of non-notification of the debtor by the security provider.

Evidently, in cases of dependent security, one has to distinguish clearly on the one hand the obligation of the main debtor, which is not as such an obligation of the security provider but merely an element determining (and fundamentally limiting) the content of the obligation of the security provider, and the obligation of the security provider in its own right: the secured obligation and the securing obligation, the obligation that may be covered, and the coverage of it by the securing obligation.

Thus, for example, one has to distinguish the interest due from the debtor on the secured obligation, which is covered by the obligation of the security provider as part of the secured right, and the interest due from the security provider itself because of its non-performance of its own obligation to pay once that obligation becomes due. The same can be said about costs of legal proceedings. Article IVG-2:104 determines which ancillary obligations of the main debtor are covered by the dependent security; the ancillary obligations of the security provider itself are determined by the general rules of Book III (as are those of the main debtor, unless more specific rules dependent on the type of relationship between the creditor and main debtor apply). Book IV $\mathrm{G}$ does not contain an explicit rule against unjust enrichment, but it should be clear that the creditor is not entitled to both types of interest for the same period of time.

\footnotetext{
E.g., in case of subsidiary liability of the security provider (Article IVG-2:106), or in case of independent personal security (Article IVG-3:103 or IVG-3:104).

Apart from the rule of interpretation where a time limit for resort to a security has been agreed (Article IVG-2:108 for dependent security c.q. IVG-3:107 for independent security, a more specific rule compared to the general rule on time-limited obligations in Article III-1:107).
} 


\subsection{Effects in the internal relationship}

As to the internal relationship, the following specific rules are found:

- For dependent security, the right of the security provider to request relief by the debtor (Article IVG-2:111).

- Both for dependent and for independent security, the rights of the security provider after performance - namely, a right to reimbursement (recourse) and a subrogation in creditors' rights (Article IVG-2:113), subject to some duties of the security provider such as notification of the (main) debtor before and/or after performance toward the creditor (Article IVG-2:112 for the case of dependent security and Article IVG-3:102 for independent security).

- Rules concerning cases involving several security providers (IVG-1:105 to 1:107).

The corresponding figure would look as follows for the subrogatory claim.

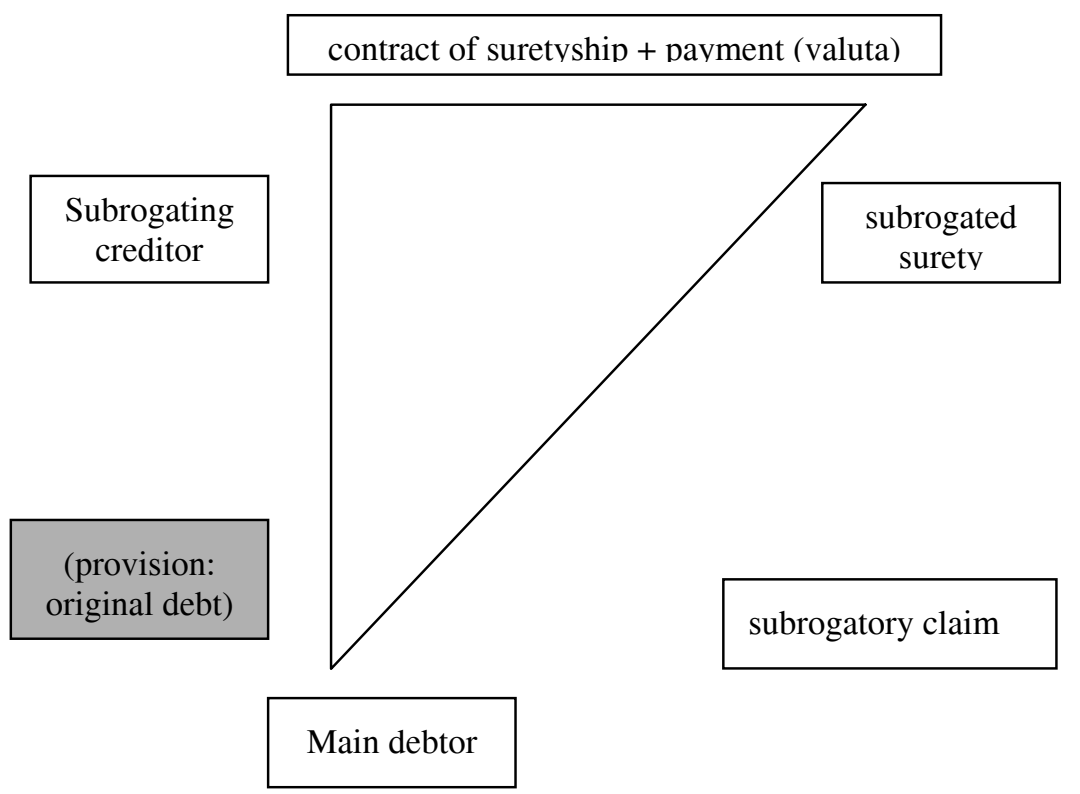

In the subrogatory relationship, the main debtor can indeed invoke all exceptions arising from the original relationship with the creditor. As to the relationship between the subrogating creditor and the subrogated creditor, the debtor can, in principle, invoke it only in order to limit the subrogation to the amount of performance by the subrogating party.

As in the case of assignment, personal subrogation entails as much a transmission of property in a right as a change in the relationship with the debtor. The rules of the DCFR do not yet really distinguish these two aspects or spell out the specific rules. In my opinion, this means that the rules on assignment must be applied with appropriate adaptations. I have discussed them in another article. ${ }^{* 8}$

Although Article IVG-4:102 seems to imply that these rules too are mandatory in cases of personal security of a consumer toward a business, I doubt that this interpretation is correct. The internal relationship is not governed by the contract between the security provider and the creditor, and these rules are therefore default rules, which can be modified as far as this can be done validly on the basis of the internal relationship itself.

\subsection{Rules on plurality of debtors}

Article IVG-1:108 provides for the subsidiary application of the rules on solidary debtors from Book III, Chapter 4-namely, Article III-4:107 and III-4:112. The other rules on plurality of debtors will further apply in cases of co-debtorship for security purposes (Article IVG-1:104). III-4:107 deals with the subrogation of the co-debtor who has performed and the associated right of recourse. These rules thus apply to co-debtorship for security purposes and subsidiarily to dependent and independent personal security, where Article IVG-2:113

\footnotetext{
8 M. E. Storme. The Structure of the Law on Multiparty-situations in the Draft Common Frame of Reference. - Juridica International 2008 (14), pp. 78-88. Available at http://www.storme.eu/ji_08_1_78.pdf.
} 
primarily governs the matter. Formulated for dependent security, IVG-2:113 applies "with appropriate adaptations" in the case of independent securities (IVG-3:109).

However, it seems as if time constraints have prevented co-ordination between these different articles. In essence, III-4:107 and IVG-2:113 say the same thing in rather different words. IVG-2:113 is more detailed and precise than is III-4:107, which is still the PECL rule, drafted before the matter was considered in greater detail by the security group and not revised since. In each of these articles, we have two concurrent remedies (IVG-2:113 (1) in fine also uses the word 'concurrent' explicitly); they are the same in essence but have different names:

- The remedy of subrogation is called subrogation in IVG-2:113 but not in III-4:107.

- The remedy based upon the internal relationship (a kind of enrichment remedy) is called recourse in the one and reimbursement in the other.

The priority for the old creditor in the case of partial performance is spelled out in both, in different words. Thus, some co-ordinating work remains to be done.

\section{Proprietary security by a third party}

Proprietary security by a third party that is not the main debtor is, in my view, also personal security. In the DCFR, the transfer of property and constitution of limited property rights are not abstract but causal. Creation of the proprietary security right thus requires an obligation of the third party to grant this right. Such an obligation is certainly an obligation to secure a right to performance of the main debtor. In that sense it is a form of personal security, even if it would not fall under the three categories defined for personal security. It follows from Article IVG-1:102 that the notion of personal security is not necessarily restricted to these three categories. But I understand the definition of 'dependent personal security' in this way as, in fact, covering these security rights, even if the obligation to grant the right is due before the performance of the secured obligation is due.

The question is relevant, i.a., for the application of Article IVG-4:103. If proprietary security by a third party is included, the creditor's pre-contractual duties provided by that article also apply in relation to a consumergrantor, which is perfectly reasonable. We should not allow creditors to circumvent the protection of consumer sureties by demanding, instead of an obligation of liability with all one's assets, the granting of security rights over all or nearly all assets. 